\title{
Модернізаційні і контрмодернізаційні тенденції в сучасному католицизмі
}

\author{
Медвєдєва Ю. Ю., Національний авіаційний університет
}

Статтю присвячено проблемі модернізації католицизму. В результаті проведеного дослідження авторкою встановлено, що значна кількість конфесійних прихильників залишилися на позиціях ортодоксального фідеїзму. Саме останній став духовно-релігійною першоосновою як для інтегрально-фашистських диктатур початку 20 століття, так і радикального розколу громадської думки, який відбувся у зв'язку з поділом католиків на прихильників етноцентризму й антисемітизму та етнічної толерантності і космополітичності. Віряни в опитуваннях не вважають таку точку зору типово католицькою. Отже вона є радше модерновою версією католицької доктрини, аніж вираженням ортодоксії.

Наголошено на тому, що контрортодоксальним та модерновим новоутворенням в руслі релігійної політики $\epsilon$ також номінальне скасування принципу непогрішимості католицької ієрархії. Папство більше не претендує на визнання своєї вищості і домінату в питаннях оцінки статусу вірян. Звісно, ця ситуація є ще доволі далекою від модернізованого християнства, проте наближає до нього принаймні в частині примирення колись поляризованих таборів - ієрократії і пастви.

Визначено, що подолання принципу непогрішимості випливає також із примирення думки папства із думкою релігійного загалу. Проте відносини священства із пересічними вірянами були істотним чином пом'якшені.

Руйнування стереотипу непогрішимості папства істотним чином розбалансувало стан із легітимаційним ресурсом католицької церкви. Дефіцит останнього спостерігався у регулюванні сімейних відносин, зокрема - ситуацій із домашнім насильством та насильством батьків над дітьми. Очільники церкви були піддані нищівній критиці за зашкарублість власного світогляду та відсутність просування шляхом модернізації.

Ключові слова: модернізація; контрмодернізація; католицизм; реформація; протестантизм; ієрократія

\section{Modernization and counter-modernization trends in catholicism modern}

\author{
Medviedieva Yu. Yu., National Aviation University
}

The article is devoted to the problem of modernization of Catholicism. As a result of the study, the author found that a significant number of confessional supporters remained in the positions of orthodox fideism. It was the latter that became the spiritual and religious foundation for both the integrally fascist dictatorships of the early 20th century and the radical split in public opinion that took place in connection with the division of Catholics into supporters of ethnocentrism and anti-Semitism and ethnic tolerance and cosmopolitanism. Believers in the polls do not consider this point of view to be typically Catholic. Consequently, it is more a modern version of the Catholic doctrine than an expression of orthodoxy. It has been noted that a nominal and cancellation of the principle of infallibility of the Catholic hierarchy should also be considered a counter-narrative and modern neo-education in line with religious policy. The papacy no longer claims to recognize its superiority and dominance in assessing the status of believers. Of course, this situation is still quite far from modernized Christianity, however, it approximates to it at least in the part of reconciliation when polarized camps are hierocrats and flock.

It is determined that overcoming the principle of infallibility follows also from the attitude of the priesthood to ordinary believers, who have been significantly relaxed. The destruction of the stereotype of the infallibility of the papacy significantly unbalanced the state with the legitimate resource of the Catholic Church. The deficit of the latter was observed in the regulation of family relations, in particular - situations with domestic violence and violence of parents over children. Church leaders were subjected to crushing criticism for the stagnation of their own worldview and the lack of progress on the road to modernization.

On this occasion, there was a long-standing debate between Catholic traditionalists and modernists, in which adherents of the two models of marriage came together.

The first group of supporters of Catholic traditionalism insisted on developing their own rules, while supporters of the modern (Catholic-Protestant) orientation insisted on a return to the orthodox understanding of Christian marriage. The inseparability of the marriage itself is based on the arguments of the dogmatic order, which are derived from Protestant theology and the relevant marriage practices.

The second direction of Catholicism's modernization can be considered to be the observance of moral and ethical standards by clerics who often abuse the mystery of confession and implement deviant sexual behavior towards the laity. It is about bringing to the disciplinary responsibility of clerics who committed such acts, in particular - the ill-treatment of children.

At the insistence of the relevant public groups interested in long-term litigation, a similar step has allowed the transition to a consistent modernization by returning to the sources, taking into account the principle of sola scriptura. For Catholicism, such an innovation is indeed one of the least precedent in the history of hierarchical hierarchies. In general, it also talks about changing the strategy of administering a higher hierarchy to gentry priests.

Keywords: modernization; counter-modernization; Catholicism; Reformation; Protestantism; hierocracy 


\title{
Модернизационные и контрмодернизационные тенденции в современном католицизме
}

\author{
Медведева Ю. Ю., Национальный авиационный университет
}

Статья посвящена проблеме модернизации католицизма. В результате проведенного исследования автором установлено, что значительное количество конфессиональных сторонников остались на позициях ортодоксального фидеизма. Именно последний стал духовно-религиозной первоосновой как для интегрально-фашистских диктатур начала 20 века, так и радикального раскола общественного мнения, который состоялся в связи с разделением католиков на сторонников этноцентризма и антисемитизма и этнической толерантности и космополитичности. Верующие в опросах не считают такую точку зрения типично католической. Следовательно, она является скорее модерновой версией католической доктрины, чем выражением ортодоксии.

Отмечено, что контрортодоксальним и модерновым новообразованием в русле религиозной политики следует считать также номинальную отмену принципа непогрешимости католической иерархии. Папство больше не претендует на признание своего превосходства и домината в вопросах оценки статуса верующих. Конечно, эта ситуация еще довольно далека от модернизированного христианства, однако приближает к нему по крайней мере в части примирения некогда поляризованных лагерей - иерократии и паствы.

Определено, что преодоление принципа непогрешимости следует также из отношения священства с рядовыми верующими, которые были существенным образом смягчены.

Разрушение стереотипа непогрешимости папства существенным образом разбалансировало состояние с легитимационным ресурсом католической церкви. Дефицит последнего наблюдался в регулировании семейных отношений, в частности - ситуаций с домашним насилием и насилием родителей над детьми. Руководители церкви были подвергнуты сокрушительной критике за косность собственного мировоззрения и отсутствие продвижения по пути модернизации.

Ключевые слова: модернизация; контрмодернизация; католицизм; реформація; протестантизм; иерократия

\section{Постановка проблеми.}

7 ерший єзуїтський папа і перший неєвропейський папа більше ніж за 1200 років розпочав проведення політики модернізації в католицизмі, заклавши фундамент для нового підходу очільництва в церкві. Модернізація торкнулася політики бідності, реформування церковної ієрархії, зміни концепції сім’ї та інших складників культури та соціальних інституцій.

Перший напрямок модернізації стосувався критики консюмеризму та олігархічних технологій управління в банківсько-фінансовому та промисловому секторах із популістсько-демократичною зорієнтованістю на найнижчі верстви суспільства.

Подібна зорієнтованість є спорідненою з практиками парафіяльного священства, що зберігає всередині себе демократичну корпоративну культуру та відповідний менталітет приязності щодо пересічних людей. У своєму виступі перед аудиторією дипломатів в травні 2013 року Френсіс зробив наголос на дотриманні етичних нормативів у сфері розподілу фінансів та споживання.

Понтифік вів мову про створення «нових кумирів», яке полягає у вшануванні золотого тільця, в культі грошей та диктатурі знеособленої економіки із дефіцитом гуманних цілей. Лідер піддав критиці гендерну та сімейну політику церкви у зв'язку з відступом від фундаменталій християнства та порушенням канонів заборони на аборти, одностатевих відносин, контрацепції.

Квінтесенцією маніфесту модерну в католицизмі стало інтерв'ю критичної спрямованості щодо церкви, яка дозволяє собі некоректні викривлення в морально-етичному вченні про любов доктрини та піддає забуттю пріоритети моральної доктрини християнства щодо служіння вдовам, сиротам, бідним та маргіналізованим членам суспільства. Понтифік створює образ загальнодоступного всім конфесіям «дому молитви», який виразно протиставляється елітистській концепції «чистої церкви», запропонованої Бенедиктом XVI [1, с. 546-549].

Очільник понтифікату констатує корупційність ватиканської бюрократії, яка культивує в своїх колах скептичне ставлення до релігійних канонів та наполягає на заміні когорти традиціоналістів із числа ревних прихильників формальних ритуалів на модерністів, які пропонують радикальні рішення у сфері очищення від корупції в церкві та оновлення моральної свідомості християнської пастви. Зазначена обставина спричинила відставку самого Бенедикта, який незадовго до своєї відставки здійснював підготовку до дебатів щодо політики церкви у сфері сім’і.

Також було взято курс на нейтралізацію корпоративно-лобістських груп у римському куріаті, що дало можливість підвищити рівень прозорості в розподілі фінансових ресурсів, а також нейтралізувати непотизм і кронізм, які стали часто практикуватися в середовищі католицької ієрократії. Понтифікатом було зініційовано новий проект щодо стабілізації ситуації на Близькому Сході у 2014 році. Від імені керівництва Ватикану було видано запрошення приймати ізраїльських і палестинських президентів на молитовному саміті у Ватикані.

Справжнім кроком модернізаційного примирення можна вважати геополітичне позиціювання католицької церкви в примирювальному векторі 
політики на Близькому Сході. Нормалізація близько-східного конфлікту на засадах християнського фундаменталізму дозволила знизити градус драматичної напруженості шляхом здійснення ритуалу примирення під стіною плачу в Срусалимі [7-10].

Понтифіком було ініційовано полеміку щодо оскарження норми про розривність шлюбу та інституційне розлучення, ставши на протестантську позицію, відповідно до якої християнський шлюб $€$ пожиттєвим союзом чоловіка і жінки, який за жодних обставин не може перериватися з будь-яких причин.

Аналіз наукових досліджень і публікацій.

3 цього приводу були спричинені довготривалі дебати між католицькими традиціоналістами та модерністами, в яких зійшлися прихильники двох моделей шлюбу.

Перша група прихильників католицького традиціоналізму наполягала на розробці власних правил, у той час як прихильники модернової (католицько-протестантської) орієнтації наполягали на поверненні до ортодоксального розуміння християнського шлюбу. Нерозривність самого шлюбу $є$ грунтованою на аргументах догматичного штибу, які є похідними від протестантської теології та відповідних практик укладання шлюбу.

Другим напрямком модернізації католицизму можна вважати дотримання морально-етичних стандартів самими кліриками, які часто зловживають таємницею сповіді і реалізують девіантну сексуальну поведінку щодо мирян. Йдеться про притягнення до дисциплінарної відповідальності кліриків, які припустилися подібних учинків, зокрема жорстоке поводження 3 дітьми [4, с. 203].

За наполяганням відповідних громадських груп, зацікавлених у довготривалих судових процесах, подібний крок дозволив перейти до послідовної модернізації шляхом повернення до витоків, приймаючи до уваги принцип sola scriptura. Для католицизму подібна інновація дійсно є однією 3 найменш прецедентних в історії ієрократичних ієрархій. Загалом йдеться також про зміну стратегії адміністрування вищого ієрокласу щодо низових священників.

Черговим модерновим кроком стало припинення формальних беатифікацій та практик особливих почестей для влади та заможних верств населення. Модернізація в протестантському руслі зреалізовується саме в контексті вшанування бідних і незаможних у порівнянні із заможними і сильними світу цього. 3 іншого боку, понтифікат започаткував міжгруповий діалог між священством та інтелігенцією світського типу, необхідний для загального покращення громадської моралі. В цьому сенсі католицизм було наближено до протестантських версій прозелітизму та роботи 3 паствою. Загальна демократизація позитивно вплинула в тому числі на відмову від беззастережної політичної підтримки диктаторських режимів та колабораціонізму [5, с. 45-114; 4, с. 225-226].

Римська ієрократія змінила свою стратегію в сфері морально-етичних стандартів, закликавши мирян приборкати консюмеризм заради стабілізації екосистемного дисбалансу на планеті. 3 цією метою було опубліковано відому енцикліку «Laudato Si». Ключові ідеї цього документу стосувалися переорієнтації пастви на радикальні трансформації ключових соціальних інститутів задля подолання наслідків глобального потепління [6, с. 118].

При цьому саме потепління оголошувалося наслідком бездумного споживацтва, яке випливає 3 недотримання норм християнського Закону. Зокрема, йшлося про бездумно-апатичне ставлення до ресурсів Землі, які нібито є невичерпними i припускають необмежену експлуатацію на догоду споживацьким примхам консюмерату.

Метою статті є побудова характеристики ключових напрямків модернізації в сучасному католицизмі. Завданнями статті $є$ : а) визначення співвідношення між автентичною християнською мораллю та моральними засадами католицизму; б) узагальнення результатів емпіричних досліджень вірян (католиків та протестантів) щодо оцінки модернізації в католицизмі.

Виклад основного матеріалу.

Проведені реформи зачепили інтереси фінансово-олігархічного лобі, яке як у Франції, так і в США стало чинити опір подібним ініціативам у вигляді режисованих ПР-акцій. Найбільшу стурбованість міжнародної фінансової олігархії викликало оголошення ватиканським священством кампанії за прийняття конвенції Організації Об'єднаних Націй з питань зміни клімату в Парижі в грудні 2004 року. Зазначеним документом кожну зі сторін зобов'язано запровадити та імплементувати екологічне законодавство, яке є спрямованим на зниження викидів, які спричиняють глобальне потепління [3, с. 60-61].

Шерега політичних лідерів США відреагувала на реформаторську екополітику католицької ієрократії своїми ініціативами. Так, Д.-А. Бохнер, очільник ініціативної парламентської групи від республіканської партії, запросив папу до виступу на з’ізді під час візиту у вересні. Захисниками політики в галузі клімату цей крок було схвалено як елемент значного просування на шляху міжконфесійного діалогу в напрямку екуменізації та модернізації.

Сам візит був стартом для критики уряду США в сфері як релігійної політики, так і соціоекономічній сфері, зокрема, сегменті зайнятості, який $є$ провідним для екологічної програми Б. Обами, названої понтифіком програмою «вбивства робочої сили».

В медіаколах реакція на модерністські заяви понтифіка про повернення до пріоритетів національних держав була доволі неоднозначною. Аналогічним чином заклики до республіканської 
партії з приводу впливу на оновлення екологічного законодавства i боротьбу з консюмеризмом також не стали популярними. Адже під гаслами модернізації відбувалося повернення до індустріального суспільства із його обмеженням споживання на користь виробництва і накопичення, які для суспільства індустріального типу завжди $є$ пріоритетними.

3 часів лютеранської реформації та модернізації церкви повернення католицизму до фундаменталій християнської етики можна розглядати як значний крок по просуванню в напрямку інституційного реформування церкви. За слушним зауваженням М. Ковальського, означені події цілком можна вважати найважливішими за останні 500 років. Історик констатує, що Друга ватиканська рада, яка відкрилася 50 років тому, змінила католицьку церкву більше ніж все інше, що сталося 3 часу, коли Лютер прибив свої знамениті 95 тез на дверях церкви в Віттенберзі [2, с. 27-38].

Модернізаційні зміни в католицькій доктрині стосувалися переважно обмеження церкви на догоду посилення держави, себто йшлося про етатизм і різноманітні компроміси із посиленням цензури в сфері права на свободу слова та свободу поширення інформації.

M. Ковальський наводить цитату 3 однієї із папських енциклік, яка передбачає подібного роду компромісність на користь забруднення християнської моралі язичницькими ліберальними міркуваннями просвітницького штибу: «Римський понтифік може і повинен примиритись із собою 1 змиритися з прогресом, лібералізмом та сучасною цивілізацією» [2, с. 35-36].

Значна кількість конфесійних прихильників залишилися на позиціях ортодоксального фідеїзму. Саме останній став духовно-релігійною першоосновою як для інтегрально-фашистських диктатур початку 20 століття, так і радикального розколу громадської думки, який відбувся у зв'язку $з$ поділом католиків на прихильників етноцентризму та антисемітизму та етнічної толерантності і космополітичності.

Віряни в опитуваннях не вважають таку точку зору типово католицькою. Отже, вона є радше модерновою версією католицької доктрини, аніж вираженням ортодоксії.

Контрортодоксальним та модерновим новоутворенням в руслі релігійної політики є також номінальне скасування принципу непогрішимості католицької ієрархії. Папство більше не претендує на визнання своєї вищості і домінату в питаннях оцінки статусу вірян. Звісно, ця ситуація є ще доволі далекою від модернізованого (фундаменталізованого) християнства, проте наближає до нього принаймні в частині примирення колись поляризованих таборів - ієрократії і пастви.

Подолання принципу непогрішимості випливає також із примирення думки папства із думкою релігійного загалу. До скасування кастовості като- ликів модернізація, звісно, ще не дійшла. Проте відносини священства із пересічними вірянами були істотним чином пом'якшені. Адже визнання можливості помилок щодо католицького корпоратіуму винесло за дужки проблеми безапеляційного звинувачення католицької церкви в причетності до злочинів фашистських диктатур.

Вичерпання аргументативної риторики досягло свого піку в лібералізації сексуальної моралі, кодекс норм якої був оновлений за рахунок дозволу послуговування протизаплідними засобами та їх використання для регуляції чисельності народонаселення планети.

Руйнування стереотипу непогрішимості папства істотним чином розбалансувало стан із легітимаційним ресурсом католицької церкви. Дефіцит останнього спостерігався у регулюванні сімейних відносин, зокрема ситуацій із домашнім насильством та насильством батьків над дітьми. Очільники церкви були піддані нищівній критиці за зашкарублість власного світогляду та відсутність просування шляхом модернізації.

Нарешті, в ієрократії перемогла консервативна доктринальна група, яка вирішила реалізувати принцип демократичності в церкві не просто на папері. Йшлося про зв'язок між чисельністю єпархій та чисельністю вірян, які $є$ мешканцями територіальних громад.

Вибори польського папи Івана Павла II в 1979 році стали початком тривалої реакції. Прогресивні діячі побачили роботу Івана Павла II як руйнування спадщини ради, за сприяння його доктринального головного кардинала Ратцінгера, який був провідним лібералом на раді, але змінив свою думку після 1968 року. Але важливо, щоб обидва очільники вважали себе консерваторами і наполягали на тому, що документи церкви були неправильно витлумаченими, а не помилковими за змістом[10].

Аргументація в цій сфері 3 боку папства в контексті відновлення старого авторитету стає все менш і менш переконливою. Адже переважна більшість сучасних католиків вже не сприймають ортодоксально-авторитарну зверхність священства. Для них є краще знайомою модернізовано-оновлена католицька модель.

Цей трансформаційний зсув може бути знаковим для розуміння подальших кроків у парадигмі меншовартісності католицького фундаменталізму у порівнянні 3 християнським фундаменталізмом при подальшому протиставленні представників різних конфесій, що умотивовує як паству, так i священство до міжконфесійного діалогу.

Готовність до діалогу простежується також у результатах опитування вірян-католиків та протестантів, які раніше вважалися непримиренно ворогуючими. Так, згідно з опитуваннями трьох підгруп протестантів, присвяченими практикам церкви та церков, подібних до католицької, проведении серед англіканців, католиків та лютеран, 


\section{було отримано наступне.}

Протестанти вважають, що тип християнства, визначений Христом у Новому Заповіті, був досконалим (оскільки Ісус є досконалим, те, що він установив, є досконалим). Тому $75 \%$ вірян засуджують дії протестантських пасторів щодо модернізації протестантських церков (у вибірці було представлено всі конфесії, крім лютеранства). 18\% припускають модернізацію християнства шляхом упровадження осучаснених літургійних практик (упровадження гучного музичного супроводу, відповідних проповідей або шоу-технологій).

Разом із цим $65,8 \%$ вірян $є$ переконаними в тому, що церква 2000 років тому не мала жодного з цих нововпроваджень. Тому проповіді Отців Церкви, вочевидь, замінювали літургію в ранніх формах християнства. 34,7\% вважають стан комунікації як у протестантських, так і в католицьких церквах незадовільним.

$28,9 \%$ респондентів у конгрегації припускають упровадження гучної концертної музики, вважаючи, що це посилює дієвість проповідей і може значно пришвидшити християнізацію потенційних адептів. Водночас вони не припускають зловживання так званими «попсовими композиціями», які не несуть духовного сенсу і справляють погане враження на новоприбульців [10].

$56,3 \%$ протестантів вважають, що католики використовують термін «модернізація християнства» як спосіб опису відсутності шанування релігійного канону та зміління теології. $\mathrm{H}$ a думку $10 \%$ опитаних, подібні тенденції є пов'язаними 3 появою «ринку» християнства 3 елементами нью-ейджизму.

Безтурботний літургійний стиль, «добре самовідчуття», поп-психологія або акцент на самооцінку, яка випливає зі світських досягнень. Отже, саме ці 10\% песимістично оцінюють зусилля щодо компромісу з культурою з точки зору стилю, які з'являються на передньому краї і передбачають зміну поколінь.

Іншим вектором в уявленнях респондентів $\epsilon$ еволюція протестантизму $(22,4 \%)$. Все, що навіть виглядає католицьким, означає прирівнювання його до поганого та неправильного. Але для католиків подібна точка зору виглядає помилковою $(45,9 \%)[7]$.

3 іншого боку, респонденти-католики не мають уявлення про те, що від початку було неправильним у християнстві, оскільки не вважають, що в католицькій церкві щось відбувалося не так, і тому відхід католицизму від раннього християнства був неістотним.

Проблема для більшості протестантів, крім англіканців, лютеран, православних, полягає в тому, що християнство почалося з Реформації і у пастви $\epsilon$ відсутніми уявлення про те, якою саме була рання християнська церква і якими практиками вона послуговувалася (67,3\%). Для католиків первинне християнство було явищем майже католицьким $(88,5 \%)[9]$.

Тому респондентам католицького віросповідання буває важко дати відповідь про те, що $\epsilon$ неправильним у ранньому християнстві, за винятком того, що вважає священство. Водночас переважна більшість протестантів $(76,8 \%)$ вважають, що первинне християнство зовсім не могло бути католицьким, а репозиціювання його як раннього католицизму виглядає нісенітницею. Отже, арифметична більшість респондентів-католиків вважає, що єдине, що було не так із раннім християнством, полягає в тому, що раннє християнство не було достатньо католицьким.

\section{Висновки.}

Респонденти-протестанти критично ставляться до великої кількості реклами, якою послуговується католицизм задля залучення пастви, що говорить про деградаційні тенденції всередині нього. Водночас протестанти, за умови визнання прогресу в протестантизмі, все одно вважають, що подальший рух від апостольських традицій все одно не сприяє зростанню релігійної культури.

Така точка зору більше стосується релігійної культури в цілому, а не тільки християнських або релігійних, але і світських організацій. Новий курс у реформах католицької моралі полягає в засудженні споживацтва, що варто визнати цілком обгрунтованим. Сучасне суспільство дійсно зловживає ресурсним та часовим марнотратством. Водночас ідеологічно-доктринальний наступ ведеться на ідоловшанування, яке стає для католицьких кіл засадничим злом.

Означені проблеми зі споживацтвом, матеріалізмом, гедонізмом ведуть до стану духовного присипляння та манії величі на грунті успіху. Високий рівень успішності в суспільствах Європи і Америки ведуть до логічного обезбоження і дехристиянізації християнства. Логічно, зростає не лише захопленість світом речей і хибна модернізації у вигляді підміни релігії наукою, але і статистика самогубств, цинічна зневіра та нігілістичне ставлення до всіх святинь.

Водночас реформування католицької церкви у векторі повернення до фундаменталій християнської етики, дебюрократизації, деієрархізації, відмови від інтерпретаторських способів донесення християнських істин може розглядатись як доволі слабкі вияви модернізаційного процесу на тлі загальної контрмодернізаційної спрямованості католицизму. 


\section{БІБІЛІОГРАФІЧНІ ПОСИЛАННЯ}

1. Гуревич П. С. Культ и культура / П. С. Гуревич // Христос и культура. Избранные труды Ричарда Нибура и Райнхольда Нибура. - М.: Юристь, 1996. - С. 546-549.

2. Ковальский Н. А. Справился ли католицизм с вызовами ХХ века? / Н. А. Ковальский // Новая и новейшая история. - 1999. - № 6. - С. 27-38.

3. Кокс Х. Мирской град: секуляризация и урбанизация в теологическом аспекте / Х. Кокс. - М.: Восточная литература, $1995 .-352$ с.

4. Нибур Р. Радикальный монотеизм и западная культура / Р. Нибур // Христос и культура. Избранные труды Ричарда Нибура и Райнхольда Нибура. - М.: Юристь, 1996. - С. 225-375.

5. Самыгин С. И. Религиоведение: социология и психология религии / С. И. Самыгин, В. И. Нечипуренко, И. Н. Полонская. - Ростов-на-Дону: «Феникс», 1996. - 672 с.

6. Тахтамышев В. Г. Библейская идеология: образ и реальность мира / В. Г. Тахтамышев. - Ростов-на Дону: изд-во Ростовского ун-та, 2000. - 280 с.

7. Pope Francis Steps Up Campaign on Climate Change (April 27, 2015)

8. Pope Francis, in Sweeping Encyclical, Calls for Swift Action on Climate Change (June 18, 2015)

9. Championing Environment, Francis Takes Aim at Global Capitalism (June 18, 2015)

10. In the Footsteps of Other Popes, Francis Seeks Worldly Change (June 18, 2015)

\section{REFERENCES}

1. Gurevich, P.S. (1996). Kul't i kul'tura [Cult and Culture]. Khristos i kul'tura. Izbrannyye trudy Richarda Nibura $i$ Raynkhol'da Nibura. (pp. 546-549). Moscow: Yurist [in Russian].

2. Koval'skiy, H.A. (1999). Spravilsya li katolitsizm s vyzovami XX veka [Has Catholicism coped with the challenges of the 20th century?]. Novaya i noveyshaya istoriya, 6, 27-38 [in Russian].

3. Koks X. (1995). Mirskoy grad: sekulyarizatsiya i urbanizatsiya v teologicheskom aspekte [Worldly City: Secularization and Urbanization in the Theological Aspect]. Moscow: Vostochnaya literatura[in Russian].

4.Nibur R. (1996). Radikal'nyy monoteizm i zapadnaya kul'tura [Radical Monotheism and Western Culture]. Khristos $i$ kul'tura. Izbrannyye trudy Richarda Nibura i Raynkhol'da Nibura. (pp. 225-375). Moscow: Yurist[in Russian].

5. Samygin, S.I., Nechipurenko, V.I., \& Polonskaya, I.N. (1996). Religiovedeniye: sotsiologiya i psikhologiya religii [Religious Studies: Sociology and Psychology of Religion]. Rostov-na-Donu: «Feniks» [in Russian].

6. Takhtamyshev, V.G. (2000). Bibleyskaya ideologiya: obraz i real'nost'mira [Biblical ideology: the image and reality of the world]. Rostov-na Donu: izd-vo Rostovskogo un-ta [in Russian].

7. Pope Francis Steps Up Campaign on Climate Change (April 27, 2015).

8. Pope Francis, in Sweeping Encyclical, Calls for Swift Action on Climate Change (June 18, 2015).

9. Championing Environment, Francis Takes Aim at Global Capitalism (June 18, 2015).

10. In the Footsteps of Other Popes, Francis Seeks Worldly Change (June 18, 2015).

\section{Медвсдсва Юлія Юріївна}

Докторант

Національний авіаційний університет

02000, м. Київ, проспект Космонавта Комарова, 1

\section{Medviedieva Yuliia Yu.}

Doctoral candidate

National aviation University

1, Kosmonavta Komarova Ave., 02000, Kyiv, Ukraine

Email: dr.yulia.medvedeva@icloud.com

Цитування: Медвєдєва Ю. Ю. Модернізаційні і контрмодернізаційні тенденції в сучасному католицизмі // Науково-теоретичний альманах «Грані». - 2018. - Т. 21. - № 4. - С. 78-83.

Citation: Medviedieva, Yu.Yu. (2018). Modernizatsiini i kontrmodernizatsiini tendentsii v suchasnomu katolytsyzmi [Modernization and counter-modernization trends in catholicism modern]. Scientific and theoretical almanac «Grani», 21(4), 78-83. 